\title{
POTENSI RUMPUT LAUT MERAH (GRACILARIA GIGAS) DAN PENAMBAHAN DAUN KENIKIR (COSMOS CAUDATUS) SEBAGAI BAHAN BAKU PEMBUATAN NORI
}

\author{
Red Algae (Gracilaria gigas) Potential as Raw Material of Nori \\ with The Addition of Kenikir Leaves (Cosmos caudatus) \\ Pinctada Putri Pamungkas*, Sudarminto Setyo Yuwono, Kiki Fibrianto \\ Jurusan Teknologi Hasil Pertanian - Fakultas Teknologi Pertanian - Universitas Brawijaya \\ Jalan Veteran, Malang - 65145 \\ *Penulis Korespondensi: email: pinctadaputri @gmail.com
}

Disubmit: 14 Desember 2017 Direvisi: 3 Januari 2018 Diterima: 7 November 2019

\begin{abstract}
ABSTRAK
Bahan baku nori umunya rumput laut jenis Porphyra, yang sulit ditemukan dan dibudidayakan di Indonesia. Kelangkaan rumput laut jenis ini diakibatkan karena Indonesia mengimpor nori kepada negara lain, yang mencapai 2 Milyar per tahun. Rumput laut merah jenis Gracilaria gigas banyak ditemukan di Indonesia dengan penambahan daun kenikir dapat dijadikan alternatif sebagai bahan baku pembuatan nori. Penelitian ini bertujuan memanfaatkan rumput laut merah Gracilaria gigas dan daun kenikir sebagai bahan baku pembuatan nori sehingga mendapatkan karakteristik fisik, kimia dengan atribut sensori yang dapat diterima konsumen. Penelitian menggunakan rancangan percobaan Rancangan Acak Kelompok (RAK) dengan 2 faktor yaitu ukuran mesh penyaringan dan konsentrasi daun kenikir yang ditambahkan. Hasil penelitian menunjukkan bahwa perlakuan penyaringan ukuran 60 mesh dan konsentrasi daun kenikir $5 \%$ menghasilkan nori Gracilaria gigas terbaik. Pada hasil analisis karakteristik kimia diperoleh nilai kadar air 11,04\%, kadar abu 6,77\%, kadar protein 22,44\%, kadar lemak 0,85\%, karbohidrat $58,91 \%$, serat kasar 9,41\%, dan aktivitas antioksidan $\mathrm{IC}_{50} 38,796 \mathrm{mg} \mathrm{AAE} / \mathrm{g}$. Pada hasil analisis karakteristik fisik diperoleh ketebalan $0,11 \mathrm{~mm}$, kuat tarik $11,23 \mathrm{~N}$, elongasi $0,65 \mathrm{~cm}$, warna $\mathrm{L}$ 42,0, warna a sebesar -0,20, serta warna b sebesar 4,3. Berdasarkan hasil analisis sensori menggunakan RATA (Rate All That Apply) dengan 100 panelis konsumen menunjukkan nori Gracilaria gigas tidak berbeda dengan nori komersil dan dapat diterima konsumen
\end{abstract}

Kata kunci : Daun Kenikir; Gracilaria gigas; Nori

\begin{abstract}
Raw material of nori is generally made of Porphyra which is hardly found and cultivated in Indonesia. Another type of seaweed, Gracilaria gigas, is found in Indonesia which can be used as the alternative raw material of nori if combined with kenikir leaf. The aim of this study is making use of the Gracilaria gigas and kenikir leaf as the ingridient of producing nori which meets the physical and chemical characteristic, and its sensory, so that it can be accepted by the consumers. Methodology of the study is using an experimental design which involves the random sampling method with two varibales, the size of filtering mesh and the concentrate of kenikir leaf. The result shows that the tretament using 60 mesh filtering and concentrate of the 5\% of kenikir leaf produces the best nori Gracilaria gigas. Analysis shows that the values of chemical characteristics are $11.04 \%$ water, $6.77 \%$ ash, $22.44 \%$ of protein, $0.85 \%$ of fat, $58.91 \%$ of carbohidrate, $9.41 \%$ of rough fiber, and $\mathrm{IC}_{50} 38,796 \mathrm{mg} \mathrm{AAE} / \mathrm{g}$ antioxidant activities. Physical characteristics are as follows, the thickness is $0.11 \mathrm{~mm}$, tensile strength is $11.23 \mathrm{~N}$, the elongation is 0.65, Colour L 42,0; colour A is -0.20, and colour B is 4.3. Based on the result of sensory analysis using RATA (Rate All That Apply) from 100 participants shows that Gracilaria gigas nori is not significantly different from the commercial nori and well accepted by the consumers
\end{abstract}

Keywords : Gracilaria gigas; Kenikir Leaves; Nori 
Jurnal Teknologi Pertanian Vol. 20 No. 3 [Desember 2019] 171-180

Potensi Rumput Laut (Gracilaria gigas) dan Penambahan Daun Kenikir [Pamungkas dkk]

\section{PENDAHULUAN}

Nori merupakan produk yang berasal dari rumput laut merah jenis Porphyra. Di Jepang, nori merupakan bahan makanan berbentuk lembaran yang dikeringkan dari rumput laut Porphyra. Menurut Loupatty (2015), banyak manfaat dari nori antara lain sebagai pembungkus sushi maupun lauk saat memakan nasi, hiasan, penyedap masakan, dan bahan makanan ringan. Tahun 2008, Indonesia mengimpor lembaran nori sebesar 21,6 milyar (65.000 metrik ton). Data tersebut menunjukkan tingginya permintaan nori dalam pemanfaatannya sebagai pembungkus sushi (Mouritsen, 2013).

Permintaan nori yang terus meningkat dan tidak tersedianya bahan baku menyebabkan Indonesia mengimpor dari negara penghasil nori. Masalah yang dihadapi dalam pemenuhan akan permintaan nori yaitu tidak tersedianya rumput laut jenis Porphyra sebagai bahan baku di Indonesia, padahal kebutuhan nori di Indonesia mencapai $80 \%$. Oleh karenanya, perlu pembuatan nori dari bahan baku alternatif rumput laut yang persediaannya banyak di Indonesia, yaitu rumput laut jenis Glacilaria gigas. Kenikir merupakan tanaman yang banyak ditemukan di Indonesia, umumnya dimanfaatkan sebagai lalapan, bumbu makan dan obat tradisional. Beberapa penelitian gizi dan obat menyebutkan kenikir mampu memperbaiki nilai gizi. Kenikir mengandung senyawa bioaktif seperti flavonoid, protein, karbohidrat, fenolat, vitamin dan mineral (Abas et al., 2003). Selain itu mengandung antioksidan yang berfungsi menangkal radikal bebas. Penambahan daun kenikir pada proses pembuatan nori yang berbahan baku utama rumput laut Glacilaria gigas diharapkan mampu menambah warna dan tekstur pada nori yang dihasilkan sehingga tidak kalah dengan nori komersial yang telah ada.

\section{METODE}

Alat yang digunakan dalam pembuatan produk diantaranya adalah panci perebus, baskom, gelas ukur $300 \mathrm{ml}$, kompor (Rinai), spatula, termometer, sarung tangan plastik, timbangan analitik (Mettle denver AA300), timbangan digital, pisau, saringan, blender (Philips), beaker glass $350 \mathrm{ml}$ dan $100 \mathrm{ml}$, cetakan plat kaca ukuran $12 \times 20 \mathrm{~cm}^{2}$, kabinet dryer, ayakan ukuran 20, 40, 60, dan 80 mesh. Bahan utama dari penelitian ini adalah rumput laut. Rumput laut yang digunakan adalah rumput laut merah jenis Gracilaria gigas yang diperoleh dari Desa Cabiya, Kecamatan Talango, Lombok (Nusa Tenggara Barat), daun kenikir yang diperoleh dari pasar Gadang Malang, dan bahan tambahan yang digunakan antara lain bawang putih bubuk, garam, gula minyak wijen dan air mineral. Nori komersil Japan, Korea, dan Singapura yang dibeli di supermarket Lai-lai Malang, Jawa Timur.

\section{Rancangan Percobaan}

Penelitian ini terdiri dari tiga tahap, tahap pertama karakterisasi nori komersil yang berada dipasaran. Tahap kedua adalah pembuatan nori menggunakan bahan bakurumput laut Gracilaria gigas, tahap disusun secara faktorial dengan dua faktor. Faktor 1 terdiri dari penyaringan dengan menggunakan ukuran mesh dan faktor II terdiri penambahan daun kenikir, diulang sebanyak 3 kali sehingga diperoleh 48 unit percobaan. Selanjutnya tahap ketiga adalah perbandingan nori komersil terbaik dengan nori Gracilaria gigas terbaik.

\section{Pembuatan Nori Gracilaria gigas}

Tahapan pertama sortasi rumput lautGracilaria gigas dan daun kenikir, rumput laut kemudian dibersihkan dari kotoran yang menempel dengan air mengalir, daun kenikir juga dicuci di air mengalir dan di ambil bagian daunnya. Rumput laut bersih direndam dalam air dengan ditambah $\mathrm{NaoH} 0,01 \%$ selama 12 jam yang berfungsi melunakkan jaringan rumput laut, dicuci kembali dengan air mengalir sampai bersih dan dilakukan penghancuran menggunakan blender. Setelah halus, rumput laut dipanaskan dengan suhu $100^{\circ} \mathrm{C}$, yang bertujuan untuk mengeluarkan gel (Cordosa et al., 2019). Selanjutnya proses pencetakan dengan plat kaca ukuran $20 \mathrm{~cm}$ x $15 \mathrm{~cm}$, Masukkan ke cabinet dryer dengan suhu $60{ }^{\circ} \mathrm{C}$ kemudian dipanaskan selama \pm 6 jam (modifikasi Freile-Pelegrín et al., 2007)

\section{Parameter yang diamati}

Parameter yang diamati pada ketiga nori komersil antara lain karakteristik kimiakadar air, kadar lemak, kadar protein, kadar abu, karakteristik fisik kekuatan tarik (tensile strength), elongasi, ketebalan dan warna (kecerahan, kemerahan, kekuningan). 
Parameter yang diamati pada bahan baku Gracilaria gigas dan daun kenikir segar antara lain analisis proksimat dan serat kasar, sedangkan parameter yang diamati pada nori Gracilaria gigas antara lain karakterisasi kimia yaitu serat kasar, kadar air, karakteristik fisik warna (kecerahan, kemerahan, kekuningan), uji kuat tarik, ketebalan, elongasi. Setelah itu, dilakukan perbandingan nori komersil terbaik dengan nori Gracilaria gigas terbaik dengan parameter kimia antara lain analisis proksimat, serat kasar dan $\mathrm{IC}_{50}$, parameter fisik meliputi warna (kecerahan, kemerahan, kekuningan), uji kuat tarik, ketebalan, elongasi dan SEM (Scanning electron microscopy) serta parameter sensori dengan metode RATA (Rate all that apply) menggunakan 100 panelis konsumen.

Analisa kadar serat kasar dilakukan menggunakan metode Sudarmadji (2007), yaitu sebanyak 1-2 g sampel nori ditimbang dan dimasukkan ke dalam labu ukur 250 ml. Tambahkan $100 \mathrm{ml} \mathrm{H}_{2} \mathrm{SO}_{4}$ (menghidrolisis serat makanan yang terkandung dalam sampel menggunakan asam) dan dipanaskan selama 30 menit. Residu disaring dengan kertas saring Whatman nomer 40, lalu dicuci dengan akuades hingga bebas asam. Residu dipindahkan ke erlenmeyer dan ditambah $200 \mathrm{ml}$ larutan $\mathrm{NaOH}$ (untuk menghidrolisis serat makanan salam sampel menggunakan basa), dan dipanaskan selama 30 menit, disaring dan dicuci dengan aquadest mendidih hingga bebas basa. Selanjutnya, dicuci kembali dengan larutan $\mathrm{K}_{2} \mathrm{SO}_{4} 10 \%, 20 \mathrm{ml} \mathrm{b} / \mathrm{v}$, dan etanol 94\% sebanyak $15 \mathrm{ml}$ (penggunaan $\mathrm{K}_{2} \mathrm{SO}_{4}$ dan etanol untuk mengendapkan serat makanan), dikeringkan selama 1-2 jam (hingga konstan), setelah itu didinginkan dalam desikator selama 10 menit lalu ditimbang. Perhitungan persentase serat kasar ditunjukkan pada Persamaan 1.

$\%$ Serat kasar $=\frac{w i-w 0}{w s} \times 100 \%$

Dengan :

Berat residu adalah berat serat kasar

w0 adalah berat kertas saring

wi adalah berat kertas saring + residu setelah pengeringan

ws adalah berat sampel

Pada aktivitas antioksidan $\mathrm{IC}_{50^{\prime}}$ sampel sebanyak 0,2 mg dilarutkan dengan aquades dengan suhu $\pm 80{ }^{\circ} \mathrm{C}$ sebanyak 10 $\mathrm{ml}(\mathrm{b} / \mathrm{v})$, kemudian dilarutkan dan dikocok menggunakan labu ukur $10 \mathrm{ml}$ hingga homogen. Sampel kemudian disaring dengan kertas saring halus hingga tidak ada partikel yang lolos kertas saring. Sampel lalu diambil sebanyak $4 \mathrm{ml}$ kemudian ditambahkan $1 \mathrm{ml}$ DPPH (ditunjukkan denganperubahan warna), kemudian dikocok dengan vortex (intensitas perubahan warna DPPH berbanding lurus dengan aktivitas antioksidan untuk meredam radikal bebas). Diinkubasi 30 menit dalam wadah gelap, kemudian diukur absorbansinya pada panjang gelombang 517 $\mathrm{nm}$. Aktivitas radikal bebas dihitung sebagai presentase berkurangnya warna DPPH dengan menggunakan Persamaan 2.

Aktivitas penangkapan radikal bebas $=\frac{\text { absorbansi kontrol-absorbansi sampel }}{\text { absorbansi kontrol }} \times 100 \%$

\section{SEM (Scanning Electron Microscopy)}

Morfologi permukaan nori Gracilaria gigas diamati di bawah SEM. Nori diletakkan diatas tempat sampel dengan menggunakan isolasi double-side. Sampel kemudian dilapisi dengan emas, lalu dimasukkan ke dalam instrumen SEM. Struktur nori diamati di layar monitor dengan menggunakan skala pembesaran 1000, dan 5000 kali. Hasil pengamatan kemudian difoto dengan menggunakan kamera digital.

\section{Analisa Statistik}

Data yang diperoleh dianalisis dengan analisis ragam dan bila perlakuan berpengaruh nyata $(\alpha<0,05)$ dilanjutkan dengan uji Tukey menggunakan program Minitab ver. 16.0 .

\section{HASIL DAN PEMBAHASAN}

\section{Karakteristik Kimia, Fisik, dan Sensori Nori Komersil}

Karakteristik kimia dan fisik nori ketiga nori komersil. Nori komersil diuji kandungan kimia antara lain kadar air, kadar abu, kadar lemak, serat kasar dan kadar protein, sedangkan uji kandungan fisik antara lain kekuatan tarik, elongasi, ketebalan dan warna L, a, dan b. Nilai kandungan kimia dan fisik tiga nori komersil dengan merek berbeda disajikan pada Tabel 1. 
Karakteristik Proksimat Bahan Baku Rumput Laut Gracilaria Gigas dan Daun Kenikir Segar

Kadar air rumput laut Gracilaria gigas bahan baku sebesar 5,84\%, kadar lemak 0,8\%, kadar protein $23,76 \%$, kadar abu $11,92 \%$, kadar karbohidrat $180,52 \%$ dan kandungan serat kasar 7,27\%. Menurut Matanjun et al., (2009), rumput laut kaya akan kandungannya seperti polisakarida, protein, dan lemak. Pada kandungan air bahan baku daun kenikir sebesar 7,41\%, kadar lemak 0,44\%, kadar protein $28 \%$, kadar abu $14,08 \%$, kandungan karbohidrat $57,52 \%$, dan kandungan serat kasar sebesar 8,62\%. Menurut Shui et al., (2005), kenikir (Cosmos caudatus) memiliki aktivitas antioksidan 49,76691 mg AAE/g dan berpotensi sebagai bahan pangan yang bersifat fungsional.

\section{Karakterisasi Kimia dan Fisik Nori Gracilaria gigas}

Kadar serat kasar nori Gracilaria gigas berkisar antara 4,74- 13,09\%. Serat kasar nori Gracilaria gigas menunjukkan perlakuan penambahan daun kenikir dan penyaringan dengan ukuran mesh berbeda berpengaruh terhadap serat kasar. Pengaruh perlakuan penambahan daun kenikir dan penyaringan dengan ukuran meshberbeda terhadap kadar serat kasar disajikan pada Tabel 2.

Tabel 2 menunjukkan peningkatan jumlah daun kenikir dan semakin kecil ukuran mesh yang digunakan menyebabkan kandungan serat kasar nori Gracilaria gigas meningkat. Sakthivel dan Devi (2015) menyatakan rumput laut jenis Gracilaria gigas mengandung serat kasar 8,9\%. Semakin kecil ukuran mesh yang digunakan pada perlakuan memiliki nilai serat kasar tertinggi.

Kadar air pada produk nori merupakan parameter penting karena nori merupakan produk bertekstur kering dan berbentuk lembaran tipis. Nilai kadar air nori Gracilaria gigas berkisar $6,31-14,1 \%$. Perlakuan penambahan daun kenikir dan penyaringan dengan ukuran mesh yang berbeda berpengaruh terhadap kadar air. Kadar air disajikan pada Tabel 3.

Tabel 3 menunjukkan peningkatan konsentrasi daun kenikir dan semakin kecil ukuran mesh menyebabkan kandungan kadar air nori Gracilaria gigas meningkat. Rumput laut dan kenikir yang lolos semakin banyak. Kadar air dipengaruhi oleh kandungan air bahan baku, rumput laut Gracilaria gigas 9,73\% (Teddy, 2009) dan sisanya berasal dari kandungan air daun kenikir sebesar 7,41\%.

\section{Karakteristik Fisik Warna}

Warna merupakan salah satu faktor penting produk pangan dan dijadikan alat penentu kualitas sebuah produk. Hasil analisa statistik menunjukkan interaksi antara perlakuan penambahan daun kenikir dan penyaringan ukuran mesh yang berbeda terhadap warna nori Gracilaria gigas yang disajikan pada Tabel 4.

Tabel 4. Nilai warna L nori Gracilaria gigas terendah sebesar 26,0 dengan perlakuan daun kenikir $0 \%$ dan penyaringan 20 mesh. Warna a sebesar 0,40, menunjukkan nori Gracilaria gigas menghasilkan warna hijau kehijauan. Warna b menunjukkan nilai 3,333. Warna yang dihasilkan nori Gracilaria gigas mendekati warna dari nori komersil. Nori dengan kualitas yang bagus memiliki warna hijau kehitaman (Yanagido et al., 2018). Ishihara et al., (2005) menyatakan bahwa warna yang didapat pada evaluasi sensori produk nori adalah warna hijau. Warna yang dihasilkan nori Gracilaria gigas berasal dari penambahan daun kenikir, kenikir secara alami mengandung klorofil yang dapat menghasilkan warna hijau

Tabel 1. Kandungan kimia fisik tiga nori komersil porphyra

\begin{tabular}{lccc}
\hline Parameter & $\begin{array}{c}\text { Nori Japan } \\
\text { "Seasoned seaweed" }\end{array}$ & $\begin{array}{c}\text { Nori Korea } \\
\text { "Mama suka" }\end{array}$ & $\begin{array}{c}\text { Nori Singapura } \\
\text { "Nico-nico" }\end{array}$ \\
\hline Kadar Air (\%) & 7,37 & 6,09 & 11,81 \\
Elongasi (\%) & 0,5 & 0,45 & 0,6 \\
Ketebalan (mm) & 0,05 & 0,07 & 0,08 \\
Warna L & 42,4 & 42,97 & 40,13 \\
Warna a & $-2,2$ & 3,4 & $-1,56$ \\
Warna b & 3,43 & 4,97 & 4,1 \\
\hline
\end{tabular}


Tabel 2. Pengaruh perlakuan penambahan daun kenikir dan penyaringan dengan ukuran mesh berbeda terhadap kadar serat kasar nori Gracilaria gigas

\begin{tabular}{ccccc}
\hline \multirow{2}{*}{ Penyaringan } & \multicolumn{4}{c}{ Konsentrasi daun kenikir } \\
\cline { 2 - 5 } & $\mathbf{0} \%$ & $\mathbf{3} \%$ & $\mathbf{4} \%$ & $\mathbf{5} \%$ \\
\hline 20 Mesh & $10,15^{\text {abcd }}$ & $10,63^{\text {abc }}$ & $12,85^{\text {ab }}$ & $13,09^{\mathrm{a}}$ \\
40 Mesh & $9,51^{\text {abcde }}$ & $9,62^{\text {abcde }}$ & $10,02^{\text {abcd }}$ & $10,05^{\text {abcd }}$ \\
60 Mesh & $6,9^{\text {def }}$ & $8,16^{\text {cdef }}$ & $8,44^{\text {cde }}$ & $9,41^{\text {bcde }}$ \\
80 Mesh & $4,74^{\mathrm{f}}$ & $6,13^{\text {ef }}$ & $6,32^{\text {ef }}$ & $6,33^{\text {ef }}$ \\
\hline
\end{tabular}

Tabel 3. Pengaruh perlakuan penambahan daun kenikir dan penyaringan ukuran mesh yang berbeda terhadap kadar air nori Gracilaria gigas

\begin{tabular}{ccccc}
\hline \multirow{2}{*}{ Penyaringan } & \multicolumn{4}{c}{ Konsentrasi daun kenikir } \\
\cline { 2 - 5 } & $\mathbf{0} \%$ & $\mathbf{3} \%$ & $\mathbf{4} \%$ & $\mathbf{5 \%}$ \\
\hline 20 Mesh & $6,57^{\mathrm{a}}$ & $8,24^{\mathrm{ab}}$ & $11,09^{\mathrm{abc}}$ & $14, \mathbf{1}^{\mathrm{abcd}}$ \\
40 Mesh & $6,23^{\text {abcd }}$ & $7,25^{\text {abcd }}$ & $10,45^{\text {abcde }}$ & $13,95^{\text {abcde }}$ \\
60 Mesh & $6,4^{\text {bcde }}$ & $7,2^{\text {cde }}$ & $10,77^{\text {cdef }}$ & $13,5^{\text {def }}$ \\
80 Mesh & $6,31^{\text {ef }}$ & $7,06^{\text {ef }}$ & $10,61^{\text {ef }}$ & $13,46^{\mathrm{f}}$ \\
\hline
\end{tabular}

Tabel 4. Pengaruh perlakuan penambahan daun kenikir dan penyaringan ukuran mesh yang berbeda terhadap warna L, a, dan b nori Gracilaria gigas

\begin{tabular}{ccccc}
\hline Konsentrasi kenikir (b/b) & Ukuran mesh & Nilai warna L & Nilai warna a & Nilai warna b \\
\hline \multirow{2}{*}{$0 \%$} & 20 & $68,37^{\mathrm{a}}$ & $4,267^{\mathrm{a}}$ & $23,300^{\mathrm{a}}$ \\
& 40 & $66,47^{\mathrm{b}}$ & $2,933^{\mathrm{ab}}$ & $21,333^{\mathrm{b}}$ \\
& 60 & $58,17^{\mathrm{c}}$ & $2,467^{\mathrm{b}}$ & $11,533^{\mathrm{g}}$ \\
& 80 & $65,73^{\mathrm{b}}$ & $2,907^{\mathrm{ab}}$ & $20,367^{\mathrm{bc}}$ \\
\hline \multirow{3}{*}{$3 \%$} & 20 & $54,57^{\mathrm{d}}$ & $2,7333^{\mathrm{ab}}$ & $19,233^{\mathrm{cd}}$ \\
& 40 & $54,20^{\mathrm{d}}$ & $2,267^{\mathrm{b}}$ & $18,133^{\mathrm{d}}$ \\
& 60 & $46,30^{\mathrm{f}}$ & $1,900^{\mathrm{bc}}$ & $7,167^{\mathrm{h}}$ \\
& 80 & $53,30^{\mathrm{de}}$ & $2,133^{\mathrm{b}}$ & $15,267^{\mathrm{f}}$ \\
\hline \multirow{3}{*}{$4 \%$} & $52,43^{\mathrm{e}}$ & $-1,300^{\text {ef }}$ & $16,923^{\mathrm{e}}$ \\
& 20 & $45,60^{\mathrm{f}}$ & $-1,133^{\text {def }}$ & $12,467^{\mathrm{g}}$ \\
& 40 & $40,57^{\mathrm{h}}$ & $0,367^{\mathrm{cd}}$ & $5,433^{\mathrm{i}}$ \\
& 60 & $41,33^{\mathrm{h}}$ & $-0,700^{\text {def }}$ & $12,333^{\mathrm{g}}$ \\
\hline & 80 & $43,37^{\mathrm{g}}$ & $0,267^{\mathrm{de}}$ & $7,700^{\mathrm{h}}$ \\
& 20 & $40,30^{\mathrm{h}}$ & $0,267^{\mathrm{de}}$ & $5,567^{\mathrm{i}}$ \\
& 40 & $26,00^{\mathrm{j}}$ & $-0,400^{\text {def }}$ & $3,333^{\mathrm{j}}$ \\
& 60 & $30,67^{\mathrm{i}}$ & $-1,500^{\mathrm{f}}$ & $4,533^{\mathrm{i}}$ \\
\hline
\end{tabular}

Tabel 5. Pengaruh perlakuan penambahan daun kenikir dan penyaringan dengan ukuran mesh yang berbeda terhadap ketebalan nori Gracilaria gigas

\begin{tabular}{ccccc}
\hline \multirow{2}{*}{ Penyaringan } & \multicolumn{4}{c}{ Konsentrasi daun kenikir } \\
\cline { 2 - 5 } & $0 \%$ & $3 \%$ & $4 \%$ & $5 \%$ \\
\hline 20 Mesh & $0,29^{\mathrm{ab}}$ & $0,34^{\mathrm{a}}$ & $0,28^{\mathrm{ab}}$ & $0,34 \mathrm{a}$ \\
40 Mesh & $0,10^{\mathrm{ab}}$ & $0,14^{\mathrm{ab}}$ & $0,10^{\mathrm{ab}}$ & $0,13^{\mathrm{ab}}$ \\
60 Mesh & $0,10^{\mathrm{ab}}$ & $0,10^{\mathrm{ab}}$ & $0,10^{\mathrm{ab}}$ & $0,12^{\mathrm{ab}}$ \\
80 Mesh & $0,09^{\mathrm{bcde}}$ & $0,09^{\mathrm{abcd}}$ & $0,06^{\mathrm{b}}$ & $0.09^{\mathrm{ab}}$ \\
\hline
\end{tabular}


dan mampu menyerupai dengan warna nori asli. Selain itu rumput laut Gracilaria gigas memiliki pigmen alami. Pigmen utama pada rumput laut adalah klorofil, karoten, phycoerithyn dan phycocyanin (Loupatty, 2015).

\section{Ketebalan}

Ketebalan salah satu karakteristik fisik produk nori. Parameter ketebalan pada bahan pembungkus dengan bentuk lembaran merupakan parameter penting. Berdasarkan hasil statistik menunjukkan penambahan daun kenikir tidak memberikan pengaruh yang nyata, namun perlakuan penyaringan ukuran mesh yang berbeda berpengaruh terhadap ketebalan nori Gracilaria gigas yang disajikan pada Tabel 5 .

Tabel 5 menunjukkan nilai ketebalan berkisar 0,34-0,06 $\mathrm{mm}$. Semakin besar ukuran penyaringan maka rumput laut yang tersaringcukup banyak sehingga ketebalan yang didapat akan semakin tipis.

\section{Kekuatan Tarik}

Kekuatan tarik merupakan besar gaya dari luar dan menyebabkan kekuatan tarik pada suatu bahan (Roohinejad et al., 2017). Berdasarkan hasil statistik perlakuan penambahan daun kenikir dan penyaringan ukuran mesh yang berbeda berpengaruh terhadap kekuatan tarik nori Gracilaria gigas yang disajikan pada Tabel 6.

Tabel 6 menunjukkan nilai kuat tarik berkisar antara 2-12,1 N. Semakin kecil ukuran mesh akan meloloskan lebih banyak.Terjadinya kekuatan tarik dikarenakan adanya saling interaksi antara ikatan hidrogen antar molekul $\mathrm{CH}_{2} \mathrm{OH}$ pada struktur agar dan $\mathrm{OH}$. Kuat tarik menunjukkan ketahanan nori (Motoyama et al., 2007).

\section{Elongasi}

Elongasi merupakan nilai maksimum perubahan panjang yang dicapai saat sampel diberikan gaya tarik dari luar hingga akhirnya terputus (Bertuzzi et al., 2012). Berdasarkan perhitungan statistika perlakuan penambahan daun kenikir dan penyaringan dengan ukuran mesh yang berbeda tidak berpengaruh terhadap elongasi nori Gracilaria gigas disajikan pada Tabel 7 .

Pada Tabel 7 terlihat bahwa nilai elongasi berkisar antara 0,2-0,7. Nilai elongasi berbanding lurus dengan nilai kuat tarik, menurut Tethool (2011), makin tinggi tensile strength, sifat bahan semakin kompak sehing- ga elongasi mengalami kenaikan. Hal yang sama dinyatakan Ogawa et al., (1991), bahwa tekstur nori Porphyra spp. yang diambil dari daerah berbeda memiliki nilai kuat tarik berbanding lurus dengan nilai perpanjangan.

\section{Penentuan Perlakuan Terbaik}

Perlakuan terbaik diperoleh dengan menggunkaan metode Multiple Attribute (Zeleny, 1987), dengan penilaian dari parameter kimia berupa kadar air, serat kasar dan parameter fisik berupa ketebalan, kuat tarik, elongasi, dan warna. Berdasarkan hal tersebut diketahui bahwa perlakuan penambahan kenikir 5\% dan penyaringan menggunakan 60 mesh menghasilkan sampel nori Gracilaria gigas terbaik.

Perbandingan Karakteristik Sifat Kimia, Fisik dan Sensori nori Gracilaria gigas dan Nori Komersil Perlakuan Terbaik

Karakteristik sifat kimia dan fisik dilakukan pada nori Gracilaria gigas dan nori komersil perlakuan terbaik yang meliputi kadar air, protein, lemak, karbohidrat, serat kasar dan aktivitas antioksidan $\mathrm{IC}_{50}$. Karakteristik fisik yaitu ketebalan, kuat tarik, elongasi, warna L, a, dan b. Karakteristik Kimia dan fisik disajikan pada Tabel 8.

Nori Gracilaria gigas memiliki kadar air sebesar $11,04 \%$ lebih rendah dibandingkan dengan nori komersil $12,81 \%$. Kadar abu nori Gracilaria gigas sebesar 6,77\%, lebih rendah dibandingkan dengan nori komersil yaitu 9,57\%. Hal ini kemungkinan disebabkan karena rumput laut Porphyra memiliki kadar abu yang cukup tinggi. Menurut Loupatty (2015), rumput laut Porphyra mengandung kadar abu 27,8\%.

Kandungan antioksidan yang terdapat pada suatu bahan pangan dinyatakan dengan $\mathrm{IC}_{50} . \mathrm{IC}_{50}$ adalah konsentrasi maksimal antioksidan yang mampu menghambat $50 \%$ radikal bebas. Aktivitas antioksidan pada Tabel 9 menunjukkan pada sampel nori Gracilaria gigas memiliki $\mathrm{IC}_{50}$ sebesar $38,796 \mathrm{mg}$ AAE/g. Menurut Zuhra et al., (2008), suatu senyawa dikategorikan sebagai antioksidan sangat kuat jika nilai $\mathrm{IC}_{50}$ kurang dari 50 $\mu \mathrm{g} / \mathrm{ml}$. Aktivitas antioksidan $\mathrm{IC}_{50}$ mendapat nilai yang tinggi, hal ini membuktikan nori Gracilaria gigas memiliki antioksidan yang sangat kuat. Daun kenikir memiliki aktivitas antioksidan sebesar 37,91 mg AAE/g.

Nilai ketebalan nori Gracilaria gigas terbaik sebesar $0,11 \mathrm{~mm}$, sedangkan nori 
komersil terbaik yaitu sebesar $0,08 \mathrm{~mm}$. Nilai elongasi sebesar 0,65 cm, sedangkan kuat tarik nori komersil terbaik yaitu sebesar 11,40 $\mathrm{N}$ dan nilai elongasi sebesar 0,75 . Nilai kuat tarik dan elongasi berbanding lurus.

Warna L, a, dan b yang dihasilkan nori komersil terbaik lebih gelap dibandingkan dengan nori Gracilaria gigas. Warna L nori komersil 40,9, sedangkan nori Gracilaria gigas 42,0 . Warna a pada nori komersil lebih hijau yaitu sebesar -1,63, sedangkan nori Gracilaria gigas 0,20 , dan warna b yang dihasilkan nori komersil sebesar 3,70, serta nori Gracilaria gigas 4,33 .

\section{Profil Sensori Nori}

Intensitas atribut sensori dinilai menggunakan metode RATA, yang mencakup 2 sampel nori terbaik dari bahan baku rumput laut yang berbeda (nori Gracilaria gigas dan nori komersil Porphyra asal Singapura).

Tabel 6. Pengaruh perlakuan penambahan daun kenikir dan penyaringan ukuran mesh yang berbeda terhadap kekuatan tarik nori Gracilaria gigas

\begin{tabular}{ccccc}
\hline \multirow{2}{*}{ Penyaringan } & \multicolumn{4}{c}{ Konsentrasi daun kenikir } \\
\cline { 2 - 5 } & $0 \%$ & $3 \%$ & $4 \%$ & $5 \%$ \\
\hline 20 Mesh & $2,7^{\mathrm{de}}$ & $2^{\mathrm{e}}$ & $2,3^{\mathrm{de}}$ & $3,6^{\mathrm{cde}}$ \\
40 Mesh & $4,96^{\mathrm{cde}}$ & $5,23^{\mathrm{cde}}$ & $6,7^{\mathrm{bcde}}$ & $7,63^{\mathrm{abc}}$ \\
60 Mesh & $10,6^{\mathrm{ab}}$ & $10,7^{\mathrm{ab}}$ & $11,4^{\mathrm{ab}}$ & $12,1^{\mathrm{a}}$ \\
80 Mesh & $6,7^{\mathrm{bcde}}$ & $7,2^{\mathrm{abcd}}$ & $7,7^{\mathrm{abc}}$ & $10,5^{\mathrm{ab}}$ \\
\hline
\end{tabular}

Tabel 7. Pengaruh perlakuan penambahan daun kenikir dan perlakuan penyaringan dengan ukuran mesh yang berbeda terhadap elongasi nori Gracilaria gigas

\begin{tabular}{ccccc}
\hline \multirow{2}{*}{ Penyaringan } & \multicolumn{4}{c}{ Konsentrasi daun kenikir } \\
\cline { 2 - 5 } & $0 \%$ & $3 \%$ & $4 \%$ & $5 \%$ \\
\hline 20 Mesh & $0,2^{\mathrm{a}}$ & $0,3^{\mathrm{a}}$ & $0,3^{\mathrm{a}}$ & $0,3^{\mathrm{a}}$ \\
40 Mesh & $0,3^{\mathrm{a}}$ & $0,3^{\mathrm{a}}$ & $0,4^{\mathrm{a}}$ & $0,4^{\mathrm{a}}$ \\
60 Mesh & $0,5^{\mathrm{c}}$ & $0,6^{\mathrm{bc}}$ & $0,6^{\mathrm{a}}$ & $0,7^{\mathrm{b}}$ \\
80 Mesh & $0,4^{\mathrm{a}}$ & $0,4^{\mathrm{a}}$ & $0,4^{\mathrm{a}}$ & $0,5^{\mathrm{a}}$ \\
\hline
\end{tabular}

Tabel 8. Karakteristik kimia, fisik nori Gracilaria gigas dan nori komersil terbaik

\begin{tabular}{lcc}
\hline Parameter & Nori Gracilaria gigas terbaik & Nori Komersil Terbaik \\
\hline Kadar air (\%) & $11,04^{\mathrm{b}} \pm 0,01$ & $12,81^{\mathrm{a}} \pm 0,01$ \\
Abu (\%) & $6,77^{\mathrm{b}} \pm 0,02$ & $9,57^{\mathrm{a}} \pm 0,01$ \\
Aktivitas Antioksidan $\mathrm{IC}_{50}$ & $38,796^{\mathrm{a}} \pm 0,184 \mathrm{mg} \mathrm{AAE} / \mathrm{g}$ & $151,047^{\mathrm{b}} \pm 0,114 \mathrm{mg} \mathrm{AAE} / \mathrm{g}$ \\
Ketebalan (mm) & $0,11^{\mathrm{a}} \pm 0,005$ & $0,08^{\mathrm{b}} \pm 0,010$ \\
Elongasi & $0,65^{\mathrm{a}} \pm 0,05$ & $0,75^{\mathrm{a}} \pm 0,05$ \\
Warna L & $42,0^{\mathrm{a}} \pm 0,100$ & $40,9^{\mathrm{a}} \pm 2,00$ \\
Warna a & $-0,20^{\mathrm{b}} \pm 0,279$ & $-1,63^{\mathrm{a}} \pm 0,150$ \\
Warna b & $4.3^{\mathrm{a}} \pm 0,800$ & $3,7^{\mathrm{a}} \pm 0,200$ \\
\hline
\end{tabular}

Tabel 9. Rata-rata nilai atribut sensori nori terbaik

\begin{tabular}{lcc}
\hline Parameter & Nori Gracilaria gigas & Nori Komersil Porphyra \\
\hline Rasa Asin & $1,83^{\mathrm{a}} \pm 0,887$ & $1,56^{\mathrm{a}} \pm 1,000$ \\
Flavor Rumput Laut (RL) & $1,97^{\mathrm{a}} \pm 0,760$ & $2,01^{\mathrm{a}} \pm 0,967$ \\
Warna Hijau & $1,90^{\mathrm{a}} \pm 0,444$ & $2,04^{\mathrm{a}} \pm 0,656$ \\
Elastisitas & $1,60^{\mathrm{b}} \pm 1,019$ & $2,11^{\mathrm{a}} \pm 0,443$ \\
\hline
\end{tabular}


Metode RATA merupakan metode kuantitatif dalam melakukan sensory profiling bertujuan mengetahui persepsi konsumen dalam menentukan karakteristik suatu produk (Fibrianto dan Dwihindarti, 2016). Melalui karakteristik tersebut dapat diketahui perbedaan antara sampel yang diujikan secara objektif. Hasilnya disajikan pada Tabel 9.

Hasil uji sensori oleh panelis konsumen, hasil sensori kedua sampel mendapatkan nori dengan karakteristik yang mendekati dengan nori komersil .

\section{Mikrostruktur}

Penampakan jaringan nori secara mikrostruktur dapat dianalisis menggunakan alat SEM (Scanning Electron Microscopy). Analisis SEM nori Gracilaria gigas dan nori komersil Porphyra dengan perbesaran 1000x disajikan pada Gambar 1 dan 2.
Gambar 1 dan 2 menunjukkan struktur permukaan nori dengan perbesaran 1000x. Struktur permukaan nori komersil lebih beraturan dibandingkan dengan nori Gracilaria gigas terbaik. Hal ini diduga karena bentuk dari thallus kedua rumput laut berbeda, rumput laut Porphyra thallus yang hallus dan berbentuk lembaran, sedangkan rumput laut Gracilaria gigas memiliki thallus berbentuk batang.

\section{SIMPULAN}

Berdasarkan hasil dari penelitian ini, disimpulkan bahwa perlakuan penambahan daun kenikir konsentrasi 5\% dengan penyaringan ukuran 60 mesh didapatkan sebagai nori Gracilaria gigas terbaik dengan

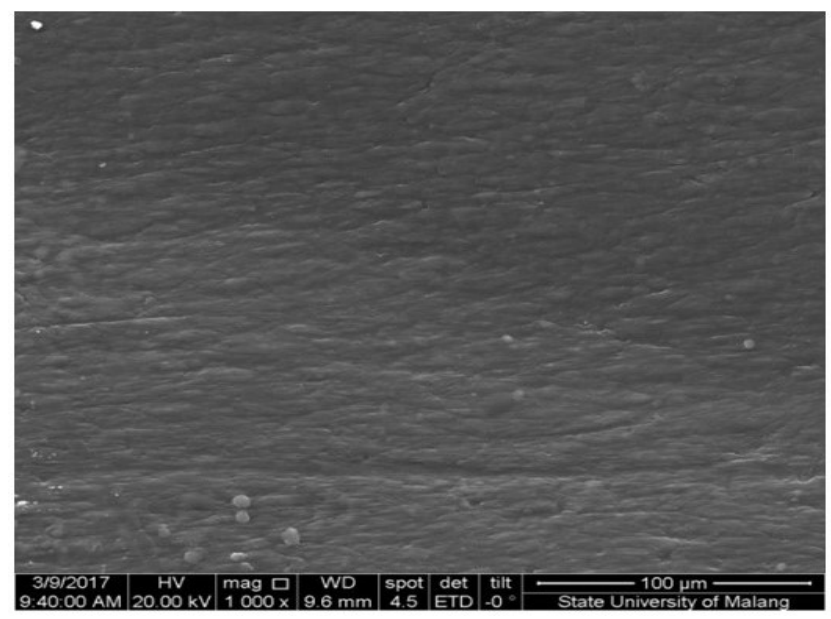

Gambar 1. Nori Gracilaria gigas

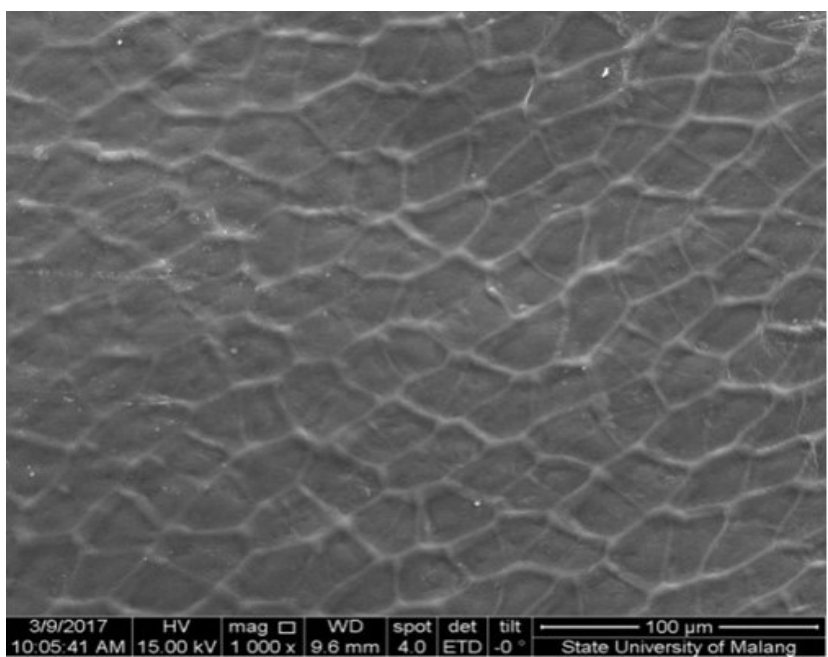

Gambar 2. Nori Komersil Porphyra 
kadar air sebesar 13,5\%, kadar abu 6,77\%, kadar protein sebesar 22,44\%, kadar lemak 0,85\%, karbohidrat 58,91\%, serat kasar 9,41 dan aktivitas antioksidan $\mathrm{IC}_{50}$ sebesar 38,796 mg AAE/g. Karakteristik fisik warna L 40,57, warna a 0,37 , dan warna b 5,43. Nilai ketebalan 0,12 mm, kekuatan tarik 12,1 N, elongasi 0,7 dengan kenampakan mikrostruktur kompak dan teratur, dengan hasil atribut sensori yang mendekati dengan nori komersil.

\section{DAFTAR PUSTAKA}

Abas, -F., Shaari, -K., Lajis, N, -H., Israf, D, -A., Umi Kalsom, -Y., 2003. Antioxidative and radical scavenging properties of the constituents isolated from Cosmos caudatus Kunth. Natural Product Sciences. 9(4), 245-248. http://journaleng. kstudy.com/ISS_Detail.asp?key $=21097$ 83\&tname $=$ kiss2002\& code $=$ undefined

Bertuzzi, M, -A., Gottifredi, J, -C., Armada, -M., 2012. Mechanical properties of a high amylose content corn starch based film, gelatinized at low temperature. Brazilian Journal of Food Technology. 15(3), 219227. http://dx.doi.org/10.1590/S198167232012005000015

Cardosa, P, -G., Grilo, T, -F., Dionisio, -G., Aurelio, -M., Lopes, A, -R., Pereira, -R., Pacheco, -M., Rosa, -R., 2019. Short-term effects of increased temperature and lowered $\mathrm{pH}$ on a temperate grazerseaweed interaction (Littorina obtusata) Ascophyllum nodosum). Estuarine, Coastal and Shelf Science. 197, 35-44. https:/ / doi.org/10.1016/j.ecss.2017.08.007

Fibrianto, -K., Dwihindarti, -M., 2016. Profiling atribut jamu kunyit asam danjamu sinom dengan metode Rata (Rate-All-That-Apply) pada beberapa kota di jawa timur. REKAPANGAN. 10(1), 15-22. http:// ejournal.upnjatim.ac.id/index.php/ teknologi-pangan/article/view/693

Freile-Pelegrín, -Y., Madera-Santana, -T., Robledo, -D., Veleva, -L., Quintana, -P., Azamar, J, -A., 2007. Degradation of agar films in a humid tropical climate: Thermal, mechanical, morphological and structural changes. Polymer Degradation and Stability. 92(2), 244-252. https:/ / doi.org/10.1016/j.polymdegradstab.2006.11.005
Hasanah, -H., 2007. Nori Imitasi dari Tepung Agar Hasil Ekstraksi Rumput Laut Merah Gelidium Sp. Skripsi. IPB. Bogor

Ishihara, -K., Oyamada, -C., Matsushima, -R., Murata, -M., Muraoka, -T., 2005. Inhibitory effect of porphyran, prepared from dried "Nori", on contact hypersensitivity in mice. Bioscience, Biotechnology, and Biochemistry. 69(10), 1824-1830. https:/ / doi.org/10.1271/bbb.69.1824

Krochta, J, M. 2002. 'Proteins as raw materials for films and coatings: definitions, current status, and opportunities'. Dalam A Gennadios (ed.). Protein-Based Films and Coating. CRC Press

Loupatty, V, -D., 2015. Nori nutrient analysis from Seawed of Porphyra marcossi in maluku ocean. Eksakta: Jurnal IlmuIlmu MIPA. 14(2), 34-48. https://doi. org/10.20885/eksakta.vol14.iss2.art4

Matanjun, -P., Mohamed, -S., Mustapha Noordin, -M., Muhammad, -K., 2009. Nutrient content of tropical edible seaweeds, Eucheuma cottonii, Caulerpa lentillifera and Sargassum polycystum. Journal of Applied Phycology. 21(1), 75-80. https:// doi.org/10.1007/s10811-008-9326-4

Motoyama, -K., Hamada, -Y., Nagashima, -Y., Shiomi, -K., 2007. Allergenicity and allergens of amphipods found in nori (dried laver). Food Additives and Contaminants. 24(9), 917-922. https://doi. org/10.1080/02652030701305454

Mouritsen, OG. 2013. Seaweeds: Edible, Available, and Sustainable. University of Chicago Press

Ogawa, -H., Oohusa, -T., Saito, -T., Iso, -N., Mizuno, -H., Fujino, -A., 1991. Texture of nori Porphyra spp. Nippon Suisan Gakkaishi. 57(2), 301-306. https:// www.jstage.jst.go.jp/article/suisan1932/57/2/57_2_301/_pdf

Roohinejad, -S., Koubaa, -M., Barba, F., -J., Saljoughnian, -S., Amid, -M., Greiner, -R., 2017. Application of seaweeds to develop new food products with enhanced shelf-life, quality and health-related beneficial properties. Food Research International. 99, 1066-1083. https://doi. org/10.1016/j.foodres.2016.08.016

Sudarmadji, S. 2007. Analisis Bahan Makanan dan Pertanian. Liberty, Yogyakarta

Sakthivel, -R., Devi, K, -P., 2015. Evaluation of physicochemical properties, proximate and nutritional composition of Gracilaria edulis collected from Palk Bay. 
Jurnal Teknologi Pertanian Vol. 20 No. 3 [Desember 2019] 171-180

Potensi Rumput Laut (Gracilaria gigas) dan Penambahan Daun Kenikir [Pamungkas dkk]

Food Chemistry. 174, 68-74. https:// doi. org/10.1016/j.foodchem.2014.10.142

Shui, -G., Leong, L, -P., Wong, S, -P., 2005. Rapid screening and characterisation of antioxidants of Cosmos caudatus using liquid chromatography coupled with mass spectrometry. Journal of Chromatography. B, Analytical Technologies in the Biomedical and Life Sciences. 827(1), 127-138. https://doi.org/10.1016/j. jchromb.2005.07.029

Teddy, M. 2009. Pembuatan Nori Secara Tradisional dari Rumput Laut Jenis Glacilaria sp. Skripsi. IPB. Bogor

Tethool, EF. 2011. Pengaruh Heat Moisture Treatment, Penambahan Gliserol Monostearat serta Rasio Campuran Tepung Singkong dan Pati Sagu terhadap Sifat
Fisikokimia Sohun. Tesis. Universitas Gadjah Mada, Yogyakarta

Yanagido, -A., Ueno, -M., Jiang, -Z., Cho, --K., Yamaguchi, -K., Kim, -D., Oda, -T., 2018. Increase in anti-inflammatory activities of radical-degraded porphyrans isolated from discolored nori (Pyropia yezoensis). International Journal of Biological Macromolecules. 117, 78-86. https:// doi.org/10.1016/j.ijbiomac.2018.05.146

Zeleny, M. 1982. Multiple Criteria Decision Making. Mc Graw Hill, New York

Zuhra, C, -F., Tarigan, J, -B., Sihotang, -H., 2008. Aktivitas antioksidan senyawa flavonoid dari daun katuk (Sauropus androgunus (L) Merr.). Jurnal Biologi Sumatera. 3(1), 7-10. http:// repository. usu.ac.id/handle/123456789/17562 